\title{
The Spanish corporate structure through interlocking directorates
}

\section{La estructura corporativa española a través del análisis de consejerías cruzadas}

\author{
Carlos Sicilia ${ }^{1}$ \\ Jose M. SALlan ${ }^{1}$ \\ PEP SIMO ${ }^{1}$ \\ Universitat Politècnica de Catalunya. BarcelonaTech (España)
}

Recibido el 8 de marzo de 2012, aceptado el 29 de abril de 2015

$\mathrm{N}^{\mathrm{o}}$ de clasificación JEL: G34, O16

DOI: $10.5295 /$ cdg. 120336 ps

\begin{abstract}
:
The aim of this paper is to determine to what extent globalization pressures are changing interlocking directorate networks modeled on continental capitalism into Anglo-Saxon models. For this purpose we analyse the Spanish network of interlocks, comparing the present structure (2012) with that of 1993 and 2006. We show how, although Spanish corporative structure continues to display characteristics of the continental economies, some major banks are significantly reducing industrial activity. Nevertheless, the financial organizations continue to maintain a close relationship with sectors such as construction and services. The analysis of the network of directorates shows a retreat in activity of industrial banking in Spain. Two large Spanish financial institutions, BSCH and La Caixa, continue to undertake activities of industrial banking in 2006, but this activity is significantly reduced in 2012. According to the theories on the role of the interlocking directorates, the companies in these sectors assure their access to banking credit by incorporating advisors from financial organizations to their board of directors. We cannot conclude that the structure of the Spanish corporate network has become a new case of Anglo-Saxon structure, but we got indications that are becoming less hierarchic as banks seem to slowly abandon centrality positions. This is especially salient if we compare the networks of 2006 and 2012, which show a continuing decrease of the role of banks and insurance companies in the network.
\end{abstract}

\section{Keywords:}

Interlocking directorates, corporate governance, corporate structure, Spain, bank control.

\section{Resumen:}

El objetivo de este trabajo es determinar en qué medida las presiones de la globalización han cambiado los modelos que siguen las redes corporativas españolas desde el capitalismo continental hacia hipotéticos modelos anglosajones. Para ello se analiza la red española de consejerías cruzadas, comparando la estructura actual

\footnotetext{
${ }^{1}$ Departament d'Organització d'Empreses, C/ Colom 11, 3rd floor, 08222 Terrassa (Spain). carlos.sicilia@upc.edu; jose.maria.sallan@upc.edu; pep.simo@upc.edu
} 
(2012) con la de 1993 y 2006. Se muestra cómo, a pesar de que la estructura corporativa española continúa mostrando características de las economías continentales, algunos de los principales bancos están reduciendo significativamente su actividad industrial. No obstante, las entidades financieras siguen manteniendo una estrecha relación con sectores como la construcción y los servicios. El análisis de la red muestra un retroceso en la actividad de la banca industrial en España. De hecho, dos de las entidades financieras españolas más importantes, BSCH y La Caixa, continuaban llevando actividades de banca industrial en 2006, pero esta actividad se reduce significativamente en 2012. De acuerdo con las teorías sobre el papel de las consejerías cruzadas, las empresas de estos sectores tratan de asegurar su acceso al crédito bancario mediante la incorporación de asesores de las entidades financieras a su consejo de administración. Finalmente, no podemos concluir que la estructura de la red de las empresas españolas se haya convertido totalmente en un modelo de estructura anglosajón, pero tenemos indicios que lentamente los bancos parece que van abandonando posiciones de centralidad. Esto es especialmente relevante si comparamos las redes de 2006 y 2012, que muestran un descenso continuo de la centralidad de los bancos y compañías de seguros.

\section{Palabras clave:}

Consejerías cruzadas, gobierno corporativo, estructura corporativa, España, control bancario. 


\section{INTRODUCTION}

Despite the unifying pressures of globalization, countries continue to display significant differences in the organization of their economic and political institutions, which determine their pattern for economic growth. In the market economies, one of those institutions is the country's corporative structure (Aguilera 1998), constructed through connections, either formal or informal, between political and economic actors (Burt 1983; Scott 1987; Zoido 1998). The characteristics of the corporative structure of a country will determine the type of capitalism adopted (Hall and Soskice 2001). One way to evaluate these relations is through the analysis of the social network defined by the interlocking directorates (Mizruchi 1996). A large number of studies exist on interlocking directorates in different countries (e.g., Ornstein 1984 for Canada; Ziegler 1984 for Germany and Austria; Gerlach 1992 for Japan).

In Spain, the most well known studies on interlocking directorates were undertaken with data from the early nineties (1993 for Aguilera's study, and 1983-1995 for Zoido's). According to these studies, Spain in the early nineties showed a continental European variety of capitalism, characterized by strong banking control (Zysman 1983; Berglöf 1990; Albert 1993; Roe 1993; Prowse 1994; Steinherr and Huveneers 1994; Sicilia et al. 2011). The central role of the banks at that time was justified by the difficulty to get access to credit, a capital market with low liquidity and few quoted companies, and an important and active participation by banks as shareholders in the most relevant companies (Zoido 1998).

Our objective is to analyze the characteristics of Spanish corporative structure in two moments of recent Spanish history: year 2006, eleven years after the most recent studies of that issue in Spain, and year 2012, after the economic disruption that has deeply transformed Spanish economic organization, specially in the financial industry. This analysis will be carried out through the examination of the social network defined by interlocking directorates between the most significant companies. This analysis will allow us to check the evolution of Spanish corporative structure, and check if it continues to correspond to continental capitalism (Aguilera 1998) or has evolved into an Anglo-Saxon model.

\section{BOARDS OF DIRECTORS, INTERLOCKING DIRECTORATES AND COR- PORATE STRUCTURE}

A large number of academic studies have analysed the influence of different supervisory mechanisms of management action on enterprise value (e.g., Jensen and Murphy 1990; Shleifer and Vishny 1997;), some of them centered on the performance of the board of directors (e.g., Baysinger and Butler 1985; Hermalin and Weisbach 1991; Yermarck 1996; Fernández et al. 1998;). In most cases, the authors of these studies consider that the main function of the board is to control firm executives on behalf of shareholders. Since the board has the power to contract, fix remuneration and dismiss managers, it has the capacity to limit their discretion (Fernández Gómez-Ansón and Fernández-Menéndez 1998), aligning management interests with those of shareholders, and therefore reducing agency costs (Fama and Jensen 1983). 
But in addition to the control function, boards of directors can also perform strategic and service functions (Zahra and Pearce 1989; Johnson et al. 1996; Hillman and Dalziel 2003). Boards perform a strategic function advising management on strategy design (Johnson Daily and Ellstrand 1996), and participating in its final approval (Golden and Zajac 2001). Finally, the members of the board also perform a service function when they allow the company to access resources, which are otherwise difficult to obtain, for example finance, or information (Hillman and Dalziel 2003). For detailed revisions about the role of board directors see Petrovic (2008).

One of the ways in which board members can carry out their service role is by participating in more than one board, thus creating an interlocking directorate. The directors who sit in more than one board create a social network, in which two companies are connected directly if they share one or more members and indirectly if they share members with a third (Burt 1979). The network of interlocking directorates determines, at least partially, the collective economic organization of the most significant companies of a country (Gerlach 1992; Hall and Soskice 2001).

Interlocking directorates can be set up for several reasons. On one hand, from the point of view of companies, they can facilitate collusion processes (Dooley 1969; Johnson Daily and Ellstrand 1996) conducive to the creation of cartels in order to reduce competition between companies. They can also act in favor of the companies in which they participate on the board when obtaining finance (Mizruchi and Stearns 1988, 1994) or obtain legitimacy with regard to interest groups (Mizruchi 1996; Haunschild and Beckman 1998). According to Allen (1974), interlocking directorates are the result of a cooperative strategy to reduce uncertainty due to the actions of other companies. Therefore, the existence of interlocking directorates can be evident of, on one hand, the intention to influence supplier companies (Mintz and Schwartz 1981), and on the other, the intention to control resources invested in other companies (Mariolis 1975; Mizruchi 1996). Also they facilitate the existence of trust relations between organizations (Bazerman and Schoorman 1983). Finally, the decision to co-opt a member belonging to another board provides access to a great amount of information that is both trustworthy and inexpensive (Haunschild and Beckman 1998), consequently interlocking directorates become a route for the diffusion of innovations and good practices (Davis 1991; Haunschild 1993). This diffusion, ultimately, facilitates institutional imitation (Haunschild 1993). Directors who participate in more than one board can also serve their individual interests as well as the group (Useem 1984). Many studies on corporative elites (Useem and Karabel 1986; Burris 2005; Westphal et al. 2006) highlight the existence of different degrees of "cohesion and coherence" (Allen 1974) between the people who make up boards of directors. Proof of this is that those members who already sit on one or more boards have a greater probability of joining a new board (Davis 1993).

The different varieties of capitalism are a consequence of the diversity of circumstances in which the processes of capital accumulation have taken place and which allow for the possibility of the industrialization of the economy and economic development (Gerschenkron 1968). The different routes taken by Germany and the United Kingdom in the development of their industrial sectors gave rise to the varieties of continental and Anglo-Saxon capitalism, respectively. In the United Kingdom, economic growth took place without the intervention of investment banks. The financing of industrial activity was undertaken using the huge fortunes obtained by families of entrepreneurs and very active and dynamic 
capital markets. In the USA the pass of the second Glass-Steagall Act, which separated the activities of commercial and investment banks, meant that banks had less importance than in the continental model when financing industrial activity. In Anglo-Saxon capitalism, the board of directors has the control management in benefit of the shareholders as its main role. On the other hand, the process of industrialization in Germany had investment banks as the initial catalysts. Investment banks, not being separated from commercial banks, allowed for the canalization of monetary flows from local savers and foreign capital into industrial activity. As a consequence, this development model brought a less developed capital market, and therefore a predominant role for banks when financing industrial activity. In the continental model, to guarantee banking finance can be an important function of the board of directors, which is why capital intensive companies will try to have bank representatives on their monitoring boards (Fligstein and Brantley 1992; Prowse 1994; Windolf and Beyer 1996). The structure of board of directors in these economies is explained by the theory of banking control. That theory advocates a central role of banks in the networks of interlocking directorates given their central role in the access to finance (Dooley 1969; Mizruchi and Fein 1999).

The industrialization of the Japanese economy took place after World War II, and although in some ways it resembles the continental model, it has characteristics of its own. We can therefore talk about a Japanese corporate structure model (Gerlach 1992; Lincoln et al. 1992; Aguilera 1998). The distinguishing elements of Japanese economic organizations have been the keiretsu. These are groups of companies joined by shareholdings, interlocking directorates and commercial and financial relations. The network of interlocking directorates reflects the relations between companies controlled by the keiretsu, whose central role is played by one or several financial organizations, typically a bank or an insurance company (Lincoln et al. 1992).

In the nineties, studies by Aguilera and Zoido characterize the Spanish economy as representative of the continental model. Zoido (1998) concentrates on the study of banks' shareholder participation in industrial companies, showing that in the period 1983-1995 the banks have a role as active investors in the majority of large Spanish companies. The banks act not only as suppliers of debt, but also as active shareholders in large Spanish companies with representatives on the majority of boards of directors of these companies. This situation benefitted both sides: on one hand, banks actively controlled the management of companies, therefore protecting their interests as well as those of other investors, and on the other hand companies ensure their access to banking finance, therefore compensating for the limited possibilities of financing through a capital market relatively lacking in capitalization when compared to Anglo-Saxon economies. According to Zoido (1998), the capitalization of the Spanish capital market in 1991 was 26.2 per cent of GDP, similar to the 25.9 per cent of the German capital market, and well below the 61.4 per cent of the American market for the same period.

Aguilera's study (1998) provides additional information of great interest to understand Spanish economic organization of the time. A revealing figure is the list of companies with highest number of interlocking directorates in 1993, shown in Table 1. The table reflects the situation prior to the privatization of public companies in 1993. As expected in a continental corporate structure, six of the thirteen companies in the table are banks. However, with the exception of $\mathrm{BCH}$, the most central companies in the network of interlocking 
directorates of the time are electric companies and state-owned companies. This situation, according to Aguilera, is a reflection of the situation inherited from the autarchic economy of the Franco era.

Table 1

Companies with greater degree of centrality in Spain in 1993

\begin{tabular}{|c|c|c|c|}
\hline Company & Sector & Ownership & Degree of centrality \\
\hline BCH & Bank & Private & 35 \\
\hline Iberdrola & Utility & Private & 34 \\
\hline Fenosa & Utility & Private & 31 \\
\hline Sevillana & Utility & Private & 26 \\
\hline BBV & Bank & Private & 19 \\
\hline Banesto & Bank & Private & 19 \\
\hline Endesa & Utility & State owned & 17 \\
\hline Telefónica & Communications & State owned & 13 \\
\hline Cepsa & Petróleo & Private & 13 \\
\hline Banco Exterior & Banco & State owned & 11 \\
\hline $\begin{array}{c}\text { Banco de } \\
\text { Fomento }\end{array}$ & Banco & State owned & 11 \\
\hline Banco Pastor & Banco & Private & 10 \\
\hline Tabacalera & Food and tobacco & State owned & 10 \\
\hline
\end{tabular}

Source: Aguilera (1998).

Spanish economic organization underwent important changes with a wave of privatizations initiated in 1988 by the Socialist party government, and continued in later years by Popular party governments (Fernández 2003). With their decisions on privatization, the governments were configuring Spain's economic organization in the 21 st century. While state shareholdings in industrial companies were sold to foreign multinational groups, shareholdings in communication, electrical and energy companies were placed on the capital market through initial public offering (IPO) (Etchemendy 2004). Governmental policy and the scarce return from the banking business at the time meant that domestic banks endorsed the majority of the institutional tranches of the flotation and a large part of the minority tranches endorsed by the public through the very same banks (Etchemendy 2004). This led to a model in which state control in these companies was replaced by control of hard core of stable shareholders, essentially banks. Another characteristic feature of the time was the inclusion of the savings banks in this process with similar regulations to those of the banks; these institutions constituted industrial groups. 
The economic rationality on which this model was based has two origins. First, when acquiring minority shareholdings in industrial companies, banks can protect their investment through debt in these companies, controlling management and avoiding problems of asset substitution (Jensen and Meckling 1976). Second, industrial groups can help to overcome the imperfections of the capital market in those countries in which it is little developed (Leff 1979). The banks' central role in industrial groups allows them to assign financial resources between the companies in the group in an efficient way, as their central position allows them to successfully gather information from all the companies that form part of it. The members of the board of directors of these companies who also make up the board of the bank have a central role in the operation of these groups. Therefore, in an economic organization as described here, banks and savings banks will have a high centrality in the interlocking directorates network.

Some recent empirical studies on the Spanish economy indicate that this model could have been evolving in recent years. Firstly, Spanish banks have been leaving their industrial groups, replacing investments in non-financial companies for shareholdings in banking businesses, both in Spain and Latin America, fitting the framework of an increasing internationalization of the Spanish economy (Binda and Iversen 2007). Some savings banks, however, have continued to maintain their industrial groups (Fernández 2003). The change in strategy by banks can be due to the Spanish capital market, which has been growing in capitalization; so industrial groups built around banks have lost part of their significance. This fact allows for the idea that the Spanish economy is coinciding with the strategy and structural patterns of other European countries, moving towards the Anglo-Saxon economic model (Galan and Sanchez-Bueno 2009). Some other studies elaborate on this kind of less bank-centered structure, although displaying a high concentration level of ownership mainly among services sector (del Orden Olasagasti et al. 2008).

Savings bank emerged in the Spanish industrial network as relevant actors in this moment. They seem to adopt a role of stable capital investors with a highly diversified inversion portfolio whilst traditional banks center its industrial participation in large national companies (Sacristán Navarro and Cabeza García 2008).

Since 2006 this evolution accelerates, mainly due to the financial crisis and its effects on the cohesive element of the network: banks and savings banks. Bank sector in Spain suffered a radical restructuring that ended in the conversion of savings banks into regular banks and, finally, an important concentration in the sector. In 2008 there were 53 main banks and savings banks, at the end of 2011 there were just 21 of them (Zafra 2011).

\section{SAMPLE AND METHODOLOGY}

For this study a compilation of information was undertaken on the makeup of the boards of directors of the top 100 Spanish non-financial companies at the end of 2006 and 2012 according to the lists published by the magazine Actualidad Economica in 2007and data obtained from SABI database in 2012. Information was obtained for 92 of the 100 companies in 2006 and the full list in 2012. In order to compare the results with those of Aguilera (1998), an attempt was made to compile the same information for the 50 main financial organizations (banks and savings banks) and the 25 main insurance companies according 
to the same source. It was possible to obtain information on 64 financial and insurance companies, therefore giving a total of 156 organizations in 2006 . For the 2012 network, in addition to the 100 largest non-financial companies, together with the 80 largest financial companies (banks, savings banks and insurance), resulting a network of 180 companies. The information was obtained from reports about corporate governance published by the Comisión Nacional del Mercado de Valores (CNMV), information provided by each organization via its own webpage or information on societies according to the SABI database. From these sources, the names of board members were garnered, codified to aid comparison, and the coincidences in names and surnames between the different boards of directors were evaluated. In this way, a matrix of affiliations between companies $\mathbf{A}$ was obtained, in which the element aij equals one if board member $i$ belongs to the board of company $j$, and zero otherwise. From matrix $\mathbf{A}$, the matrix $\mathbf{M}=\mathbf{A}^{\prime} \mathbf{A}$ was constructed, in which mij is the number of interlocking directorates between companies $i$ and $j$ (Scott, 2000). This matrix is the adjacency matrix of the social network, and defines the graph with values or weighted graph of interlocking directorates, in which the nodes are the companies in the sample considered, and every pair of companies with interlocking directorates $(i, j)$ is united by an edge with an associate value equal to mij. From matrix $\mathbf{M}$ the matrix of the binary graph $\mathrm{B}$ was obtained, through $b i j=1$ if the corresponding $m i j$ was different from zero, and $b i j=0$ in the opposite case.

The importance of each member of the social network is evaluated through its degree centrality. The nodes with high centrality will be those that have a great number of relationships with other members of the network (Freeman 1979). Through the UCINET program (Borgatti et al. 2002) different indicators of centrality have been obtained for each node on the weighted and binary graphs.

In order to consider the importance of the indirect connections, two other measures of centrality are calculated for each node of the binary graph: closeness centrality and betweenness centrality. Social network members that are at a lesser distance than the other members will be those that have greater proximity centrality. The closeness centrality for a node $\mathrm{i}$ is calculated as the inverse of the sum of geodesic distances between $i$ and the rest of nodes. UCINET provides the standardized proximity centrality with respect to the most central node in the network. Companies with high closeness centrality will have greater ease in accessing others, not only with those they are directly connected to, but also with those with which they have indirect links. The betweenness centrality for node $i$ is calculated by evaluating the number of times that $i$ is in the shortest path between any other pair of nodes. The companies with high betweenness centrality will have a privileged position when acting as intermediaries between companies without direct connections.

Since different economic organizations are renowned for, among other things, the more or less central role of banks in the network, a social network for sectors of activity has been defined, grouping together companies in the network in the same fifteen sectors of activity defined by Aguilera (1998). In this network, the nodes are the activity sectors. Following a procedure similar to that undertaken previously for individual companies, a weighted undirected graph has been obtained in which the nodes are activity sectors, instead of companies. Two sectors of activity will be connected by an edge if at least one interlocking directorate exists between companies in these sectors. For each of the groups we have studied its degree centrality, which enables the evaluation of the intensity of relations with other 
groups, as well as the number of connections between companies in the same sector. The defined sectors of activity, as well as complementary information, can be found in Table 2 .

Table 2

Sectors of activity with interlocking directorates within and outside the sector in 2006

\begin{tabular}{|c|c|c|}
\hline Sector & $\begin{array}{c}\text { Internal board } \\
\text { linkages }\end{array}$ & $\begin{array}{c}\text { External board members } \\
\text { (degree of centrality) }\end{array}$ \\
\hline Food and food processing & 0 & 8 \\
\hline $\begin{array}{c}\text { Construction and contracting } \\
\text { Light industries, textile and leather, wood, } \\
\text { paper and printing }\end{array}$ & 5 & 71 \\
\hline Chemicals & 0 & 11 \\
\hline Cement & 0 & 8 \\
\hline Iron \& Steel & 0 & 11 \\
\hline Machinery & 0 & 7 \\
\hline Cars & 0 & 11 \\
\hline Transportation & 0 & 31 \\
\hline Communication & 0 & 50 \\
\hline Energy / Public utilities & 6 & 34 \\
\hline Wholesaling and retail trade & 4 & 93 \\
\hline Banking & 8 & 20 \\
\hline Services & 6 & 27 \\
\hline Insurance & 1 & 8 \\
\hline
\end{tabular}

Source: developed by authors.

\section{RESULTS}

The network of companies in year 2006 is made up of a main component of 92 companies, and four dyads. The other companies are isolated. In Table 3 are listed the companies with a higher degree of centrality in the weighted graph, with the same format as Aguilera (1998). When comparing data for years 1993 and 2006, it is evident that in the 2006 network there is a significant reduction in the number of financial companies with high centrality. Although in the 2006 network are included the savings banks, unlike Aguilera, of the six banks in the 1993 network there are only two left: BSCH and La Caixa. The concentration of the banking sector in these thirteen years does not completely explain the retreat by the banks: while BCH occupies first place in the 1993 list (35 interlocking directorates), $\mathrm{BSCH}$, a merger of the Santander bank with $\mathrm{BCH}$, occupies seventh place in 
2006 with just 14 interlocks. The weight of BSCH in 2006 is in fact somewhat less than that of Banesto in 1993. The other large Spanish bank in 2006, BBVA, is not part of the main connected component of the network.

The 2012 network is much less connected, although its structure is similar to the 2006 network: a large component, some small ones and many isolated companies. In this case, the main component is made up of 53 companies, there are 14 small components being dyads or formed of up to 4 elements, and, finally, 91 unconnected companies. From the companies in the main component 19 are financial companies and 2 of them insurance. Table 3 shows that in 2012 centrality degrees have decreased in general and that highest central bank is Banco de Santander (formerly BSCH) although below Bankia, formed by the merge Caja Madrid and some other minor savings banks.

Table 3

Companies with greatest degree of centrality in 2006 and 2012

\begin{tabular}{|c|c|c|c|c|c|}
\hline Company & Sector & $\begin{array}{c}\text { Degree of } \\
\text { centrality } \\
\mathbf{2 0 0 6}\end{array}$ & Company & Sector & $\begin{array}{c}\text { Degree of } \\
\text { centrality } \\
\mathbf{2 0 1 2}\end{array}$ \\
\hline Abertis & Transportation & 21 & Indra sistemas & Industrial & 9 \\
\hline Unión Fenosa & Utility & 21 & $\begin{array}{c}\text { Hidroelectrica del } \\
\text { cantabrico }\end{array}$ & Utility & 6 \\
\hline ACS & $\begin{array}{c}\text { Construction } \\
\text { and transpor- } \\
\text { tation }\end{array}$ & 17 & Bankia & Bank & 5 \\
\hline Sogecable & Mass media & 16 & $\begin{array}{c}\text { Fomento de } \\
\text { construcciones y } \\
\text { contratas }\end{array}$ & $\begin{array}{c}\text { Construction } \\
\text { and transpor- } \\
\text { tation }\end{array}$ & 4 \\
\hline Altadis & $\begin{array}{c}\text { Tobacco and } \\
\text { Logistics }\end{array}$ & 15 & Iberdrola & Utility & 4 \\
\hline CASER & Insurance & 15 & $\begin{array}{c}\text { Obrascon huarte } \\
\text { lain }\end{array}$ & $\begin{array}{c}\text { Construction } \\
\text { and transpor- } \\
\text { tation }\end{array}$ & 4 \\
\hline BSCH & Bank & 14 & $\begin{array}{c}\text { Petroleos del } \\
\text { norte }\end{array}$ & Oil & 4 \\
\hline PRISA & Mass media & 13 & Telefonica & Communication & 4 \\
\hline CEPSA & Oil & 11 & $\begin{array}{c}\text { Banco de } \\
\text { santander }\end{array}$ & Bank & 3 \\
\hline Iberia & Airline & 11 & Banco gallego & Bank & 3 \\
\hline La Caixa & Savings bank & 10 & $\begin{array}{c}\text { Banco grupo } \\
\text { cajatres }\end{array}$ & Bank & 3 \\
\hline Vitalicio & Insurance & 10 & Banesto & Bank & 3 \\
\hline AGBAR & Utility & 9 & Cableuropa sa & & 3 \\
\hline
\end{tabular}




\begin{tabular}{|c|c|c|c|c|c|}
\hline Generali & Insurance & 9 & $\begin{array}{c}\text { Cepsa comercial } \\
\text { petroleo }\end{array}$ & Oil & 3 \\
\hline Repsol YPF & Oil & 9 & Cepsa quimica & Oil & 3 \\
\hline & & & $\begin{array}{c}\text { Iberia lineas ae- } \\
\text { reas de españa }\end{array}$ & Airline & 3 \\
\hline & & & $\begin{array}{c}\text { Industria de dise- } \\
\text { ño textil }\end{array}$ & Industrial & 3 \\
\hline & & & $\begin{array}{c}\text { Repsol petroleo } \\
\text { les españa }\end{array}$ & Oil & 3 \\
\hline & & & Union fenosa gas & Utility & 3 \\
\hline
\end{tabular}

Source: developed by authors.

As well as the centrality of the weighted graph, three other measurements of centrality have been evaluated: the centrality in the binary graph, closeness centrality and betweenness centrality. With the exception of closeness centrality, all indicators display a high correlation, which is why we can state that they represent approximately equivalent centrality.

An examination of the connections of companies with higher indicators of centrality reveals that many of those connections take place between those same companies. Figure 1 shows the relations between the companies with greater centrality in 2006 . The subgraph shows a high density: between these nine companies there are 17 connections, with a total of 29 interlocking directorates. The nine companies belong to 7 different sectors of activity. Union Fenosa, one of the companies with the highest centrality in the network, is connected with the rest of the companies of the subgraph, except Altadis. Among the most notable of Union Fenosa's connections are its relations with financial organizations: it shares members not only with BSCH, but also with three other financial organizations: the Banco Pastor, Caixa Nova and the Caja de Ahorros del Mediterráneo. The insurance company CASER is connected with three other companies in the subgraph (Abertis, Altadis and Unión Fenosa), but owes its high centrality to the fact that it shares members with seven savings banks. These directorates have a clear aim to control, as CASER is the insurer for the Spanish savings banks.

In 2012 there is also a nucleus of densely-connected highly-central companies although it is somewhat less intertwined than in 2006. In this core some banks (Liberbank, Banca March, banco Mare Nostrum) are present among industrial (Indra) and utility companies (Hidroeléctrica del Cantábrico) 
Figure 1

Subnet of the most central companies in 2006

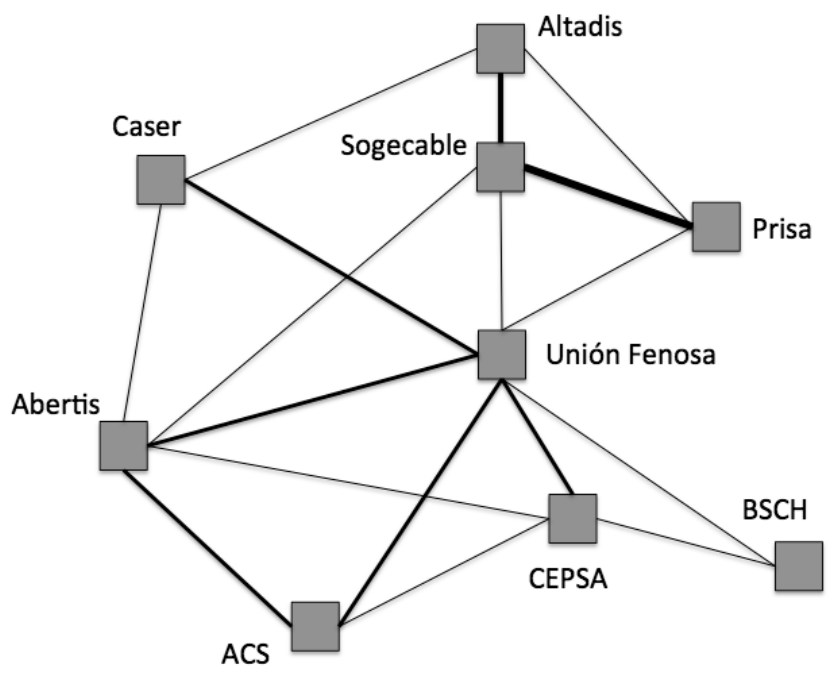

Source: developed by authors.

Figure 2

Subnet of the most central companies in 2012

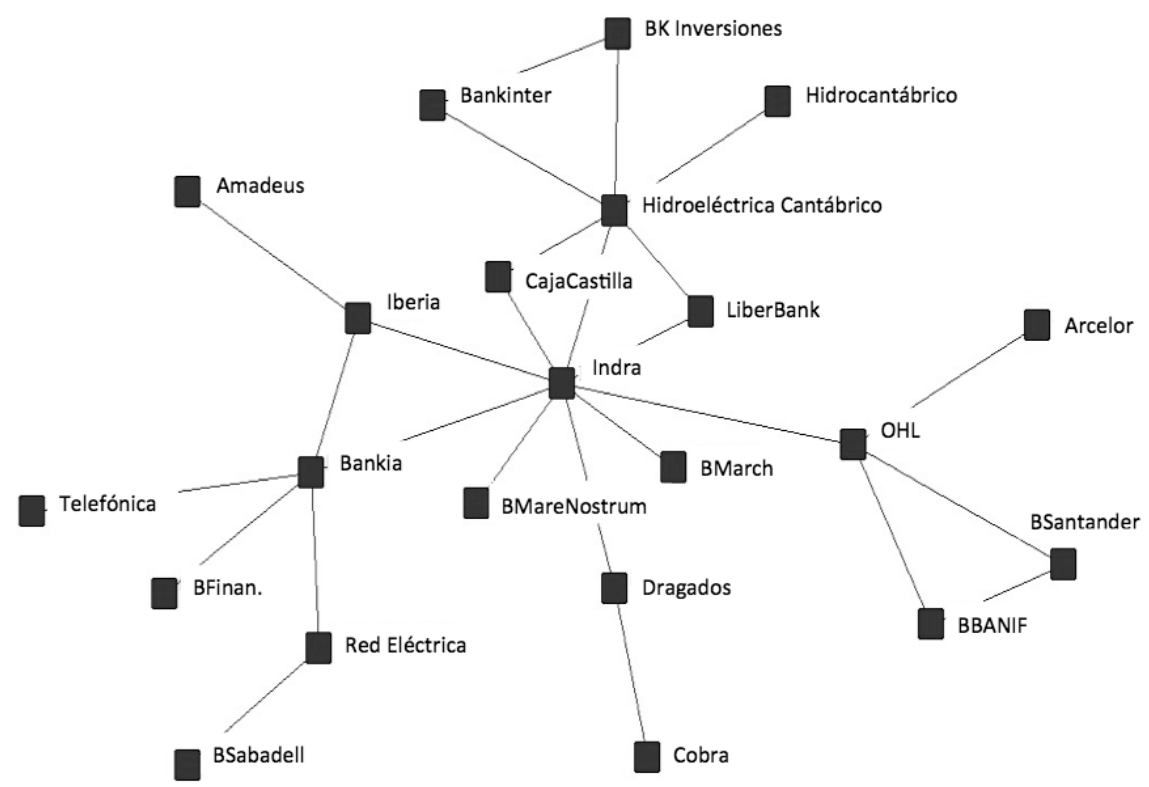

Source: developed by authors. 
If we compare the ranking for the most central companies in the 1998 network with that of 2006, we see that the presence of financial organizations has reduced notably. This reduction has been even greater in the 2012 network. There may be two reasons for this: First, the progressive concentration of the banking sector: Banco del Fomento, BCH and Banco Exterior have been acquired by other organizations (although financial organizations are the most represented sector in the network, due to the manner that the sample is selected). The second is that other financial organizations have reduced significantly their interlocking directorates.

While the BBV could count on 19 interlocking directorates in 1998, in 2006 the BBVA can only count on one and in 2012 none. The Banco Pastor has gone from 10 directorates in 1998 to only three in 2006 and just one with Targobank from its own group in 2012. Two financial organizations have a high centrality in the directorate's network: BSCH, which appears in the group of more central companies in the network, and la Caixa, whose importance in the network requires more detailed analysis. In 2012 the centrality of La Caixa seems to decline while BSCH, now Banco de Santander remains at the head of the list.

$\mathrm{BSCH}$ is the financial organization with highest centrality: it is the seventh company in number of interlocking directorates, the sixth in the number of companies with interlocking directorates (centrality in the binary graph), and third in betweenness. It has interlocking directorates with ten companies, as can be seen in Figure 2. Of these ten companies, two are insurance (Mutua Madrileña and Generali), another is financial (Banesto) and the other seven are non-financial organizations. This pattern of interlocking directorates demonstrates important industrial activity and is representative of $\mathrm{BSCH}$ policy, the company with highest degree centrality in 1998. Another remarkable fact is that the companies that $\mathrm{BSCH}$ is connected to also have high centrality: $\mathrm{BSCH}$ is either less or equal in distance to two of 39 companies in the network. This means that their members participate in the Board of Directors, or share participation with members in approximately 40 per cent of the biggest Spanish companies.

Banco de Santander seems a good example of the reduction of network density. In 2012 the Santander is only connected with Obrascon-Huarte-Laín (OHL) and Fomento de Construcciones (FCC), two large construction companies, apart from Banif, from its own group. So, from being at the centre of a diverse structure of companies in a variety of sectors, Santander holds connections with just two construction companies, leaving some companies unconnected (although others as Indra remain at the network's core).

The second financial organization whose pattern of relations revealed important industrial activity was La Caixa. In 2012 this savings bank had low values of centrality: it was 24 th position in centrality by number of companies, 11 th for centrality in number of members, and 44th for betweenness centrality. Nevertheless, it had interlocking directorates with five companies with high centrality: Abertis, AGBAR, Gas Natural, Repsol YPF and Sogecable. This fact enabled it to be either less or equal in distance two of 29 companies in the network. In 2012 La Caixa only keeps a connection with its own group's Nuevo Micro Bank and with Telefonica. Seems that, again, an important cohesive actor in the network has lost this role.

Some of the companies in the network display an inverse pattern of relations to that predicted in the theory on banking control. While this theory predicts that financial organizations will have connections with a large number of companies, on some occasions we 
see that some companies have many connections with financial organizations. The clearest case is that of CASER in 2006: 11 of their 15 interlocking directorates come from seven savings banks. In this case, these members are there to control, since CASER shares were held to a large degree by the Spanish Savings banks. Two other relevant cases are those of Abertis and Unión Fenosa.

\section{Figure 3}

\section{Egonet of Banco Santander Central Hispano in 2006}

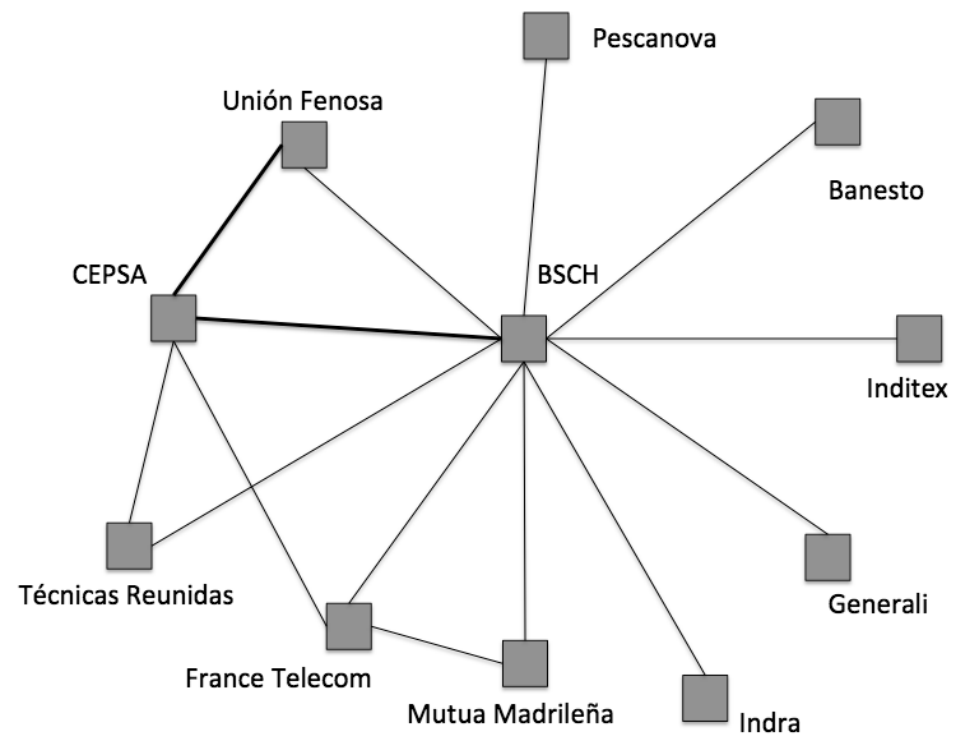

Source: developed by authors.

Figure 3 shows the graph of relationships between sectors. With respect to the 1998 network, there are continuing close relationship between banks and constructors (24 interlocks), companies in the energy sector (19 members) and insurance (18 members). A large part of these connections can be explained by the abundant presence of savings banks on the boards of CASER and Union Fenosa. With respect to the 1998 network, the relationship between the financial sector and the chemical sector is significantly weakened (only two members) and the relationship with the cement sector disappears. These results can be explained by these sectors' loss of weight in the sample of major companies, as both have only two companies, the two being multinationals in the chemical sector. The financial sector continues to maintain the same level of relationship with other sectors, such the steel industry and machinery manufacturing. Other sectors with close relationships are construction and energy, with 13 interlocking directorates, and communication and distribution, with 10 members. 
Figure 4

Graph collapsed by industrial sectors in 2006

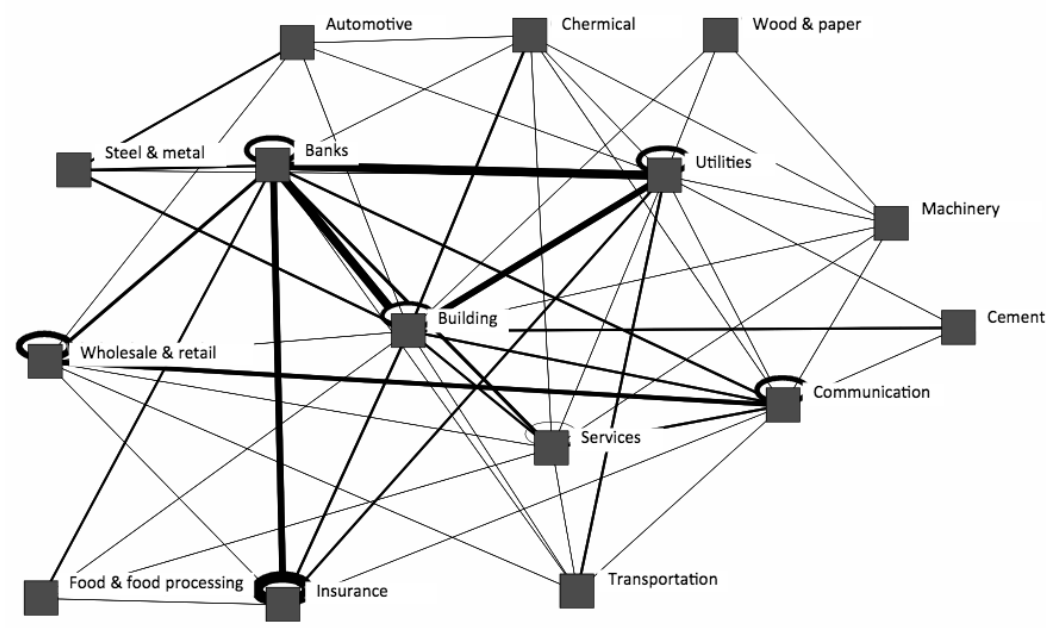

Source: developed by authors.

The relationships between companies belonging to the same sector are also appreciable; as they can demonstrate an attempt to coordinate the operations of these companies with the purpose of winning market share and limit the effects of the competition. The sectors with the highest number of internal interlocking directorates are insurance, with 16 members, and distribution, with 8 members. The financial sector displays only six interlocking directorates, corresponding to three relationships between banks with two members on each (Bancaja with Banco de Valencia, Banco de Andalucía with Banco Popular and Banesto with BSCH). Considering that during a large part of the twentieth century the Spanish banking sector had intensively used interlocking directorates in order to act as a de facto monopoly (Pueyo 2006), the data for 2006 shows a remarkable change in tendency. Take into account that also one of the two large Spanish banks, BBVA, remains outside the main connected component of the network.

As already indicated, close intra-sector relationships appear in the construction and infrastructure sector. Also, in both sectors there is a strong relationship with the banking sector. In the construction sector, the most obvious case is Abertis, which has interlocking directorates with two other large companies in the sector, ACS and Metrovacesa. Figure 5 shows a partial network with these three companies in the 2006 network. 
Figure 5

Partial graph of the 2006 network with Abertis, ACS and Metrovacesa in red

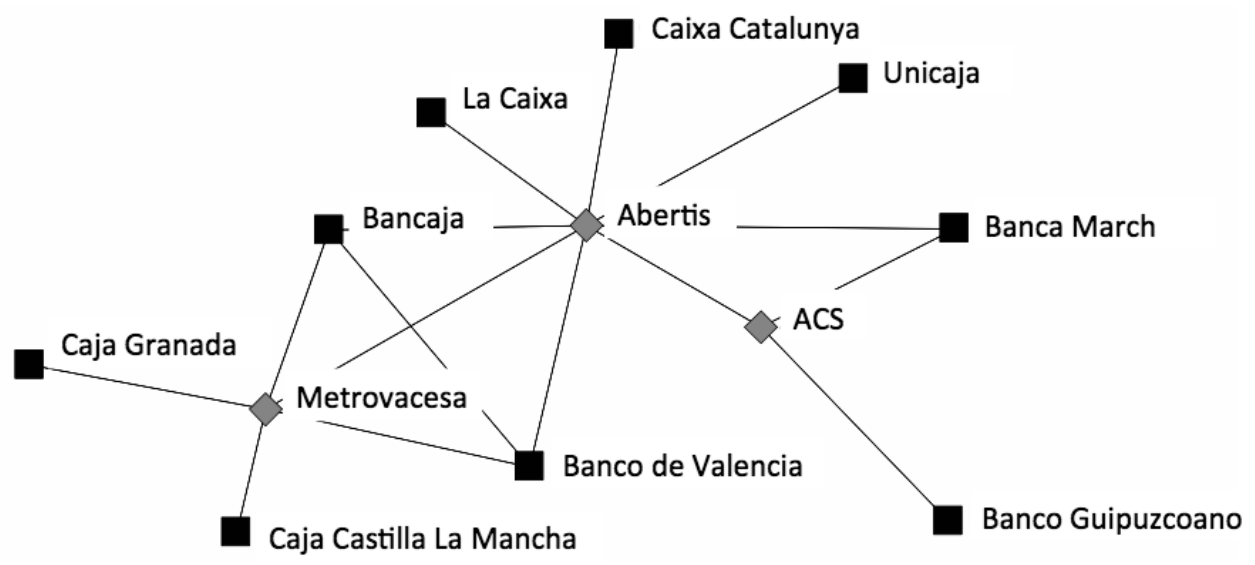

Source: developed by authors.

\section{DISCUSSION, CONCLUSIONS AND FUTURE LINES OF RESEARCH}

Revisiting the network of interlocking directorates thirteen and nineteen years after Aguilera's study (1998) allows us to go deeper into the role that interlocking directorates play on the boards of directors of large Spanish companies, the evolution of the banks' role in Spanish corporate structure, and the evolution of the model of capitalism in Spain. An in depth analysis of the network of members shows us that many of the interlocking directorates have a control function. In the 2006 network, examples of this control function can be found in CASER, controlled by savings banks, or the five interlocking directorates between Sogecable and the PRISA Group, the twelve interlocking directorates between insurance companies Generali, Estrella and Vitalicio. On the other hand, the analysis of the network of directorates shows a retreat in activity of industrial banking in Spain. Two large Spanish financial institutions, $\mathrm{BSCH}$ and La Caixa, continue to undertake activities of industrial banking in 2006, but this activity is significantly reduced in 2012. The interlocking directorates between banks and non-financial companies have reduced significantly, although close relationships continue to exist between the financial sector and other sectors.

A great part of the relationships between banks and savings banks and non-financial companies should be interpreted as an attempt by the latter to ensure banking finance. This is the case in the most capital-intensive sectors: construction and energy. In this way, the companies diversify their means of access to banking finance, reducing their dependency on this resource. In these cases, the interlocking members would undertake a service function, reducing the uncertainty associated to the provision of this resource (Pfeffer and Salancik 1978).

Interlocking directorates can also serve to facilitate collusion between companies in the same sector. In that case, the interlocking directorates have a strategic function in both companies (Ferruz Agudo et al. 2008). The relationships between companies in the same 
sector, or compatible sectors, could be a demonstration of this behavior, specifically if they are established between firms that should compete for the same markets. This would be valid only when interlocked firms don't acknowledge to belong to the same business group As can be seen in Table 2, only relatively few intra-sector interlocking directorates exist in the 2006 network. The only case of possible coordination between companies in the same sector is the network around Abertis, ACS and Metrovacesa as shown in Figure 5. So, as the intra-sector interlocking directorates between potentially competing corporations are scarce, there is no evidence that they serve this particular objective in this context. Nevertheless, this does not mean that interlocks could not be used to facilitate collusion in other manners, for example facilitating the self-serving interests of a capitalist class (Fitch and White 2005; Carroll and Sapinsky 2010)

In the studies of networks of interlocking directorates, banks and savings banks can play a central role, given that the activity of industrial banking leads them to take significant shareholdings in industrial companies, and therefore to have representatives on the boards of these companies. As stated before the only financial organizations that develop an activity of industrial banking in 2006 are BSCH and La Caixa. This result confirms the forecasts by previous contributions (Fernández 2003; Poveda et al. 2014), in the sense of a reduction in the weight of industrial banking activity on behalf of the banks, whereas the savings banks are increasing their industrial activity in their local markets and is consistent with the study of the industrial participation of banks and saving banks by the time (Sacristán and Cabeza 2008). As previously indicated, it is more frequent that a non-financial company has representatives of various banks and savings banks on its board, than a bank has shareholdings in various industrial companies. This fact shows that, although the Spanish capital market gained in dynamism and size (Etchemendy 2004), in some sectors it is considered necessary to maintain interlocking directorates in order to diversify sources of banking finance.

Finally, this study has contributed to the evaluation of corporate structure evolution in the Spanish economy. The analysis of the network of interlocking directorates shows an economy halfway between Anglo-Saxon and continental capitalism. On the one hand, the number of interlocking directorates between the financial sector and non-financial companies has been reduced significantly, if we compare the networks in 1993 and 2006. This trend has become more salient in the 2012 network. This may indicate that the economic disruption suffered by the Spanish economy from 2008, that has affected significantly the financial sector, has accelerated the evolution of the Spanish economy to an Anglo-Saxon network. In addition, we observed that important players in the financial sector do not develop industrial banking activity, at least with large companies. On the other hand, the network of interlocks between sectors shows a pattern of relationships similar to that of 1993, although some of the relationships have weakened. This pattern is typical of a corporative structure in which banks continue to play a central role, although less than in other European economies, such as Germany (Ziegler 1984). The process of economic and monetary union with Europe, the progressive internationalization of Spanish banking, the necessary restructuring of the savings banks, and the predictable expansion of capital markets in Spain can act as forces which lead the Spanish corporative structure towards the Anglo-Saxon model, and towards the convergence with other countries in our vicinity.

So the network of Spanish interlocking directorates reflects partially theory predictions. We have found that interlocks act as a means to secure the resource capital for those sectors 
in which is important and as a form of control and supervision from banks to indebted enterprises. Notwithstanding these supporting facts, we have not found interlocks to facilitate collusion between organizations in the same sectors as they are supposed to do.

This work shows that the number of interlocking directorates between financial organizations has been reduced significantly along 2006 and 2012, if we compare the present situation with a large part of the twentieth century (Pueyo 2006). However, intense relationships continue to exist between the financial sector and other sectors, such as insurance, energy and construction. A longitudinal analysis of the relationships between these sectors and the financial sector could help to understand the evolution of Spanish corporate structure, and to evaluate if Spain is giving way to the pressures of globalization and converging with the economies in its circle, or rather keeps its own model concerning the social networks established in its business fabric.

We cannot conclude that the structure of the Spanish corporate network has become a new case of Anglo-Saxon structure, but we got indications that are becoming less hierarchic as banks seem to slowly abandon centrality positions. This is especially salient if we compare the networks of 2006 and 2012, which show a continuing decrease of the role of banks and insurance companies in the network (De Andrés et al. 2014). Its displacement away from continental organization is consistent with movement shown in other traditionally continental economies (Heemskerk and Fennema 2009).

This paper has some other limitations, which in turn can also lead to future lines of investigation. One limitation corresponds to the sample selected, which does not include the whole network of Spanish companies, and which over-represents financial companies, which are just under a third of the sample. This sample was chosen in order to be able to compare the results obtained with those of Aguilera (1998), and considering it improbable that board members of large companies participate on boards of small or medium-sized companies. The fact that a large part of the non-financial companies in the sample don't have interlocking directorates leads to the thought that the results obtained are representative of the relationships between large Spanish companies. However, the evidence of strong industrial banking activity by savings banks, and observations by Fernandez (2003) and Sacristán and Cabeza (2008) lead us to think that the examination of relationships between savings banks and companies in their local circles could give very interesting results, in the sense to determine empirically the possible influence of local governments on the management of savings banks. These relationships should not be limited to interlocking directorates, but rather examined from a wider perspective.

Another interesting line of investigation could be the evaluation of the existence of clannish control mechanisms (Useem 1984; Useem and Karabel 1986) in Spanish corporate structure. The examination of the global network of directorates shows that between a few companies, with great weight in the Spanish economy, a wide network of interlocking directorates has been woven (see Figure 1). It is significant that several of these companies are ex-state companies, privatized only relatively few years ago (Bel and Costas 2001; Arocena 2004). The analysis of the network of members, in which the nodes are board members, and the edges have an equal value to the number of boards shared by each pair of members, could demonstrate the existence of a management elite with significant influence on the Spanish economy. 


\section{REFERENCES}

Aguilera, R.V., 1998. Directorship interlocks in comparative perspective: The case of Spain. European Sociological Review, 14(4), 319-342.

Albert, M., 1993. Capitalism against capitalism. Whurt Publishers: London.

Allen, M.P., 1974. Structure of interorganizational elite cooptation - interlocking corporate directorates. American Sociological Review, 39(3), 393-406.

Arocena, P., 2006. Privatisation Policy in Spain: Stuck Between Liberalisation and the Protection of Nationals Interest, in Privatization experiences in the European Union, eds Marko Köthenbürger and Hans-Werner Sinn. MIT Press: Cambrige, MA, pp. 339-364.

Baysinger, B.D. and Butler, H.N., 1985. Corporate governance and the board of directors: Performance effects of changes in board composition. Journal of law, economics and organization, 1, 101-124.

Bazerman, M.H. and Schoorman, F.D., 1983. A limited rationality model of interlocking directorates. Academy of Management Review, 8(2), 206-217.

Bel, G. and Costas, A., 2001. La privatización y sus motivaciones en España: De instrumento a política. Revista de Historia Industrial, 19, 39-65.

Berglöf, E.,1990. Capital structure and mechanisms of control: A comparison of financial systems, in The firm as a nexus of treaties, eds M.Aoki, B. Gustafson, \& O. Williamson, Sage, London, pp. 237-262.

Binda, V. and Iversen, M.J., 2007. Towards a 'managerial revolution' in european business? The transformation of danish and spanish big business, 1973-2003. Business History, 49, 506-530.

Borgatti, S.P., Everett, M.G. and Freeman, L.C., 2002. Ucinet for windows. Software for social networks analysis. Harvard, MA: Analytic Technologies.

Burris, V., 2005. Interlocking directorates and political cohesion among corporate elites. American Journal of Sociology, 111(1), 249-283.

Burt, R.S., 1979. Structural theory of interlocking corporate directorates. Social Networks, 1(4), 415-435.

Burt, R.S., 1983. Corporate profits and cooptation: Networks of market constraints and directorate ties in the American economy. New York: Academic Press Inc.

Carroll, W. K., and Sapinski, J. P., 2010. The Global Corporate Elite and the Transnational Policy-Planning Network, 1996-2006: A Structural Analysis. International Sociology, 25(4), 501-538.

Davis, G., 1991. Agents without principles - the spread of the poison pill through the intercorporate network. Administrative Science Quarterly, 36(4), 583-613.

Davis, G. 1993. Who gets ahead in the market for corporate directors: The political economy of multiple board memberships, in: Academy of Management Best Papers Procedures in 1993, pp. 202-206.

De Andrés, P., Blanco-Alcántara, D. and López-de-Foronda, Ó., 2014. Los interlocking directorates en España. Evolución, poder y consejeros independientes. Revista Internacional de Sociología, 72(1), 83-114.

Del Orden Olasagasti, O. and Garmendia Lazkano, A., 2008. Estructuras de propiedad y grupos empresariales en España. Ekonomiaz, (68), 102-133. 
Dooley, P.C., 1969. Interlocking directorate. American Economical Review, 59(3), 314323.

Etchemendy, S., 2004. Revamping the weak, protecting the strong, and managing privatization: Governing globalization in the spanish takeoff. Comparative Political Studies, 37, 623-651.

Fama, E.F. and Jensen, M.C., 1983. Separation of ownership and control. Journal of Law \& Economics, 26(2), 301-325.

Fernández, A.I., Gómez-Ansón, S. and Fernández-Menéndez, C., 1998. El papel supervisor del consejo de administración sobre la actuación gerencial. Evidencia para el caso español. Investigaciones Económicas, 22, 501-516.

Fernández, Z., 2003. Banca y empresa industrial en España, 1978-2003. Economía Industrial, 1-2(349-350), 193-202.

Ferruz Agudo, L., Marco Sanjuán, I. and Acero Fraile, I., 2008. Evolución temporal de los códigos de buen gobierno en España, Boletín Económico del ICE, 2948.

Fich, E. M., and White, L. J., 2005. Why do CEOs reciprocally sit on each other's boards? Journal of Corporate Finance, 11, 175-195.

Fligstein, N. and Brantley, P., 1992. Bank control, owner control, or organizational dynamics - who controls the large modern corporation, American Journal of Sociology, 98(2), 280-307.

Freeman, L.C., 1979. Centrality in social networks conceptual clarification. Social Networks, 1(3), 215-239.

Galan, J.I. and Sanchez-Bueno, M.J., 2009. Strategy and structure in context: Universalism versus institutional effects. Organization Studies, 30, 609-627.

Gerlach, M.L., 1992. The japanese corporate network - a blockmodel analysis. Administrative Science Quarterly, 37(1), 105-139.

Gerschenkron, A., 1968. Atraso económico en su perspectiva histórica. Barcelona: Ariel.

Golden, B.R. and Zajac, E.J., 2001. When will boards influence strategy? Inclination x power = strategic change. Strategic Management Journal, 22, 1087-1111.

Hall, P.A. and Soskice, D., 2001. Varieties of capitalism. Oxford Univ Press, Oxford

Haunschild, P.R., 1993. Interorganizational imitation: The impact of interlocks on corporate acquisition activity. Administrative Science Quarterly, 38(4), 564-592.

Haunschild, P.R. and Beckman, C.M., 1998. When do interlocks matter? Alternate sources of information and interlock influence. Administrative Science Quarterly, 43(4), 815-844.

Heemskerk, E. and Fennema, M, 2009. Network Dynamics of the Dutch Business Elite. International Sociology, 24(6), 807-832.

Hermalin, B.E. and Weisbach, M.S., 1991. The effects of board composition and direct incentives on firm performance. Financial Management, 20(4), 101-112.

Hillman, A.J. and Dalziel, T., 2003. Boards of directors and firm performance: Integrating agency and resource dependence perspectives. Academy of Management Review, 28(3), 383-396.

Jensen, M.C. and Meckling, W.H., 1976. Theory of the firm: Managerial behavior, agency costs and ownership structure. Journal of Financial Economy, 3(4), 305-360.

Jensen, M.C. and Murphy, K.J., 1990. CEO incentives- it's not how much you pay but how. Harvard Business Review, 3, 138-153.

Johnson, J.L., Daily, C.M. and Ellstrand, A.E., 1996. Boards of directors: A review and research agenda. Journal of Management, 22(3), 409-438. 
Leff, N.H., 1979. Entrepreneurship and economic development: From classical political economy to economic sociology. Journal of Economic Literature, 17, 46-64

Lincoln, J.R., Gerlach, M.L. and Takahashi, P., 1992. Keiretsu networks in the Japanese economy - a dyad analysis of intercorporate ties. American Sociological Review, 57(5), 561-585.

Mariolis, P., 1975. Interlocking directorates and control of corporations - theory of bank control. Social Sciences Quarterly, 56(3), 425-439.

Mintz, B. and Schwartz, M., 1981. Interlocking directorates and interest group formation. American Sociological Review, 46(6), 851-869.

Mizruchi, M.S., 1996. What do interlocks do? An analysis, critique, and assessment of research on interlocking directorates. Annual Review of Sociology, 22, 271-298.

Mizruchi, M.S. and Fein, L.C., 1999. The social construction of organizational knowledge: A study of the uses of coercive, mimetic, and normative isomorphism. Administrative Science Quarterly, 44(4), 653-683.

Mizruchi, M.S. and Stearns, L.B., 1988. A longitudinal-study of the formation of interlocking directorates. Administrative Science Quarterly, 33(2), 194-210.

Mizruchi, M.S. and Stearns, L.B., 1994. A longitudinal-study of borrowing by large American corporations. Administrative Science Quarterly, 39(1), 118-140.

Ornstein, M., 1984. Interlocking directorates in Canada - intercorporate or class alliance. Administrative Science Quarterly, 29(2), 210-231.

Petrovic, J., 2008. Unlocking the role of a board director: a review of the literature. Management Decision, 46(9), 1373-1392.

Pfeffer, J. and Salancik, G.R., 1978. The external control of organisations. New York: Harper and Row Publishers.

Poveda, G., Sicilia, C., Simo, P. and Sallan, J.M., 2014. Análisis longitudinal de las consejerías cruzadas y su papel en la organización económica española. Harvard Deusto Business Research, 3(2): 64-73.

Prowse, S., 1994. Corporate governance in an international perspective: A survey of corporate control mechanisms among large firms in the United States, the United Kingdom, Japan and Germany. Basle: Bank of International Settlements.

Pueyo, J., 2006. Relaciones empresariales y consejeros comunes en la banca española del siglo XX. Investigaciones de Historia Económica, 6, 137-168.

Roe, M., (1993). Some differences in corporate structure in Germany, Japan and the United States. Yale Law Journal, 102(8), 1927-2003.

Sacristán Navarro, M. and Cabeza García, L., 2008. Participaciones industriales de la banca española: contexto, evolución y situación actual. Ekonomiaz, (68), 156-181.

Scott, J., 1987. Intercorporate structures in Western Europe: A comparative historical analysis, in Intercorporate relations. The structural analysis of business, eds M.S. Mizruchi \& M. Schwartz, Cambridge University Press, New York, pp 208-232.

Scott, J., 2001. Social Network Analysis. $2^{\text {nd }}$ edition. London: Sage Publications.

Shleifer, A. \& Vishny, R.W. (1997). A survey on corporate governance. Journal of finance, 52, 737-783.

Sicilia, C., Lordan, O., and Gonzalez-Prieto, D., 2011. The business prestige: A preliminary study based on interlocks within companies. Intangible Capital, 7(2), 585-610. 
Steinherr, A. and Huveneers, C., 1994. On the performance of differently regulated financial institutions - Some empirical evidence. Journal of Banking \& Finance, 18(2), 271-306.

Useem, M., 1984. Inner circle: Large corporations and the rise of business political activity in the US and UK. Oxford: Oxford University Press.

Useem, M. and Karabel, J., 1986. Pathways to top corporate management. American Sociological Review, 51, 184-200.

Westphal, J.D., Boivie, S. and Chang, D.H.M., 2006. The strategic impetus for social network ties: Reconstituting broken CEO friendship ties. Strategic Management Journal, 27(5), 425-445.

Windolf, P. and Beyer, J., 1996. Co-operative capitalism: Corporate networks, in Germany and Britain. British Journal of Sociology, 47(2), 205-231.

Yermarck, D., 1996. Higher market valuation of companies with a small board of directors. Journal of Financial Economy, 40, 185-213.

Zafra, V., 2011. La segunda oleada de fusiones en la banca española es inminente. Público: Madrid, 28 de noviembre de 2011.

Zahra, S.A. and Pearce, J.A., 1989. Boards of directors and corporate financial performance - A review and integrative model. Journal of Management, 15(2), 291-334.

Ziegler, R., 1984. The network of interlocking directorates and financial participations among german and austrian corporations. Kolner Zeitschrift Fur Soziologie Und Sozialpsychologie, 36(3), 585-614.

Zoido, E., 1998. Un estudio de las participaciones accionariales de los bancos en las empresas españolas. Investigaciones Economicas, 22(3), 427-467.

Zysman, J., 1983. Governments, markets and growth: Financial systems and the politics of industrial change. New York: Cornell University Press. 